\title{
Correlation Analysis of Employees' Payment and Corporate Performance in Listed Company
}

\author{
Jinghua $\mathrm{Ji}^{1}$, Dan Chang ${ }^{2}$ \\ ${ }^{1,2}$ College of Business Management, Changchun University of Technology, Changchun Jilin,130012, \\ China
}

Keywords: Listed company, Employees' payment, Enterprise performance.

\begin{abstract}
In recent years, the speed of national development is very fast. Affected by listed company, state-owned enterprises develop to a better direction. There is rather direct employees' payment and enterprise performance in listed company. Employees' payment, average payment, etc. could have an effect on working enthusiasm. Thus, listed company should pay attention to such problems, adopt effective measures to make perfect scheme to promote employee performance in listed company and establish good basis for its development. According to the analysis of domestic and overseas studies, this article proposes some pertinence of employees' payment and enterprise performance for leaders' reference.
\end{abstract}

\section{Introduction}

At present, employees' performance problem in listed company is a quite important research project. Researchers of economics find that leaders in some listed companies think little of employees' motivation and can not better promote its value in enterprises, resulting in inefficient promotion of corporate performance. When the setting of payment is not scientific, employees would not accept payment changes which is not good for national development. Thus, high-position employees' in listed company should attach importance to such problem, adopt effective measures to set correlated payment content and guarantee better promotion of enterprise performance.

\section{Domestic and overseas study}

\section{Overseas study}

When overseas economists study the relation of employees' payment and enterprise performance, in order to better promote study efficiency, it chooses two large-scale service companies as study samples and observe the study structure, finding that payment in service industry doesn't reduce, with quite fast growth rates and even the growth rates are different, there is no wide change. The payment characteristic mentioned above is rigid. As to the payment distribution in America, there is certain down tendency. Analyzing payment rigidity finds when labor contract is not sound, the setting of payment could promote cooperation efficiency. Some economists shows that the payment rigidity is limited by government laws and regulations and such payment distribution mode is very suitable for the development of China's listed companies, mainly because employees' payment is controlled by government at present. It could guarantee better promotion to employees' living standard and avoid polarization ${ }^{[1]}$.

\section{Domestic study}

At present, among the domestic research result to basic level employees' payment, it shows that control to company payment is rather passive in our country which can not effectively motivate 
employees' enthusiasm. From the long-term angle, payment management and control could promote human cost and make listed companies getting some use capital. In addition, during the payment management and control process, it reduces production efficiency in listed company. According to the study to payment theory and related data change, during the salary sample change process, rigid payment management is not suitable for promoting enterprises performance. Comparing to payment downward changing, payment upward changing could better promote enterprises performance. In a similar way, payment downward changing is bad to promote enterprises performance ${ }^{[2]}$.

\section{Pertinence in listed companies between employees' payment and companies}

\section{Relation of employees' payment and enterprise performance in listed companies}

If the mangers in enterprises want to promote business performance effectively, they should stimulate employees to attach importance to their work and play their own management responsibility, using the most direct and effective way to promote employees' payment standard and stimulate employees' working enthusiasm. That is to say, according to employees' working condition, it is to compensate with payment to further promote enterprises performance. As for managers, such management mode could not only promote management level but also effectively enhance enterprises profit efficiency. The operation target in listed companies is to maximize profit while employees' expectation is to best develop their own payment level. Thus during communication and exchange process of enterprises and employees, the most direct is the relation between enterprises profit and employees' payment. Payment incentive way is to avoid employees without due diligence in their pots and to stimulate employees to promote working enthusiasm under the drive of market economy. The employees' would become lazier when their payment level is lower ${ }^{[3]}$. To some extent, employees' payment would develop in a positive direction and it is more possible for them to promote working performance to bring bigger positive development for enterprises. When enterprises link up employees' performance with payment, it could reduce monitoring cost because such payment mechanism itself has some monitoring function. Employees' payment level is mutually correlated with enterprises performance. No matter which department in enterprises, the final employees' payment level would directly show the enterprises performance as well as their working condition. Therefore, it could promote not only enterprises economic benefit but also the company to develop with a steady pace and make its performance reaching to maximization ${ }^{[4]}$.

\section{long-term influence of rigid adjustment of employees' payment to enterprises performance}

As for the rigid adjustment to employees' payment setting, according to mutation analysis of enterprise performance and employees' payment, it is to analyze the rigid and elastic setting to employees' payment. By relative comparison, during the elastic setting process to employees' payment, the increase of payment has some incentive function to employees and positive function to the enterprise performance growth. As for the rigid setting to employees' payment, the payment adjustment has no certain relation to enterprises performance and there is no incentive function to employees by the increase of payment. Employees' behaviors are affected by their labor and payment condition. Employees working hard is for the certain payment and to get some award according to enterprises profit, such as promoting payment level, the title of a technical post, etc. If enterprises could inspire employees with payment at a suitable opportunity, employees' value could be reflected and enterprises performance could go up. As for all the partners, the enterprises performance would directly decide their cooperation results. During enterprises promoting performance, if employees' payment level is promoted, it could effectively promote employees' working enthusiasm and further enhance enterprises performance development. During employees' working process, their performance would be awarded with extra payment. Thus they would work harder for more awards. At the same time, when enterprises grant awards to employees, it could enhance their loyalty to promote team spirit. By comparison, if enterprises reduce payment, or give punishment to employees during work, enterprises performance would also descend and cost would rise, with some economic 
risks. Thus, to avoid enterprises performance descending and economic benefit lowering, employee personage would promote working enthusiasm to enhance enterprises performance. In general condition, when enterprises performance is promoted, employees would hope their payment level rising and getting awards. When the payment is with rigid rising, it shows that employees has made more economic benefit for enterprises but without corresponding labor payment and praise from enterprises, which would make employees working less hard. During the development process in the future, enterprises performance would also descend. The rigid setting of employees' payment being downward developing means enterprises performance descending but not affecting employees' payment level, which is also covert award to employees. It shows that during the rigid payment model upward process, employees' working enthusiasm would descend. During rigid payment model downward process, employees' labor cost would increase, which is good for enterprises performance rising. As for the rigid characteristic of payment, the increase of payment would even have negative function, reducing not only performance but also economic benefit. As for the elastic setting of payment, the increase of payment would have positive function, which could promote employees' enthusiasm and be good for enterprises' development ${ }^{[5]}$.

\section{Sample analysis in study}

During data gathering process, this article extracts samples respectively from two large service enterprises. As for sample analysis, it considers the following points. Firstly, it is to add up the quality of financial information and all kinds of data in sample company to show its influence factors. At the same time, it can not take financial listed company as the object of study, mainly because the financial property and financial regulations in other ordinary service listed companies are different. Thus it needs to eliminate abnormal listing of financial listed companies and insurance listed companies. To insurance companies with unsound financial regulations, it can not research listed companies before 2006 to guarantee the integrity and accuracy of materials.

Variables of study objects is expressed by the following ways. Firstly, when calculating common employees' payment changes, it should use their payment to minus the payment of board of directors or each management echelon. As for the calculation of payment growth rate, it should observe neighboring several months' payments to guarantee better calculation. As for the enterprises performance, it should use pretax profit to compare to the average total assets. As for the performance in prior period, it should use performance in current period to minus that in the first period. As for the performance growth condition, it should compare neighboring several months' performances. As for the rigid payment condition, if employees' payment growth and enterprises performance present negative direction, enterprises payment is with rigid characteristic; if that present positive direction, then it is with elastic mode.

As to the employees' payment in listed company, the writer makes critical variable distribution description according to the average wage and growth condition of domestic company employees. I is observed that company has some profitability when performance rising, but with not high profitable level, which shows that different listed companies have different performances. According to the analysis to payment condition in this company, it finds that employees' payments have big differences and their payment level is quite low, only few company employees with payment level.

\section{Setting suggestions to the employees' payment mode in listed company}

\section{To perfect payment making system}

As for the employees' payment setting in listed company, the perfect system is of great concern. Rigid characteristic or polarization of employees' payment is mainly due to payment level in listed company not changing with company performance. Thus during making such system, it should pay attention to pertinence of employees' payment level and enterprises performance to guarantee better promoting establishment efficiency of payment market. As to different industrial developments and regional 
conditions, it should adjust enterprises business activities according to market economy development situation and competition trend as well as payment system. During the process to make employees' payment system, it should attach importance to risk investment, explaining employees' payment by market risk and guarantee rationality and legality to further promote designing scientificity of payment system in market and establish favorable basis.

\section{To build sound performance evaluation system}

As to employees' payment adjustment in listed company, it should adjust according to their performances and establish sound performance evaluation system, which could not only show employees' performances effectively but also promote correlation of employees' performance with payment. On the basis of making payment system, listed company should also set favorable performance evaluation system according to market economy. By evaluating employees' performances, company would use correct way to rationally adjust and change their payment, playing the advantage of payment system to reach some incentive functions. At present, in each listed company in China, there are several changes of employees' payment. The first is the basic income. In general condition, it would adjust annual payment system. The second is the performance reward. Most companies would increase payment awarding level. In addition, as to various systems in enterprises, it could perfect performance evaluation system by improve system. Using monitoring system, etc. to assess employees' performances could make it with effective supervision and avoid nonstandard work. In addition, as to the wage management department in listed company, publicity of payment could effectively promote incentive functions. It should make sure the payment in this year has some changes to that in last year and explain the causes to make obvious correlation of employees' payment and enterprises performance.

\section{Conclusion}

According to the analysis of payment situation in listed company and study of sample, it finds that there is rather direct relation between Xi'an employees' payment and enterprise performance. During the promotion process of employees' payment, the enterprise performance would also be promoted, and the setting of employees' payment should possess some incentive function to better promote working enthusiasm and enhance enterprise performance. During the development of listed company, it should enhance each negative effect setting by payment to play incentive function and effectively enhance competitive capacity of listed company on the basis of enhancing employees' payment.

\section{References}

[1] Li Zhu, Controller Nature, Employees' Payment and Enterprise Performance - Based on Experimental Evidence in China's Listed Companie, Chongqing University, 2011.

[2] Li Peigong, Shen Yifeng, Managers' Payment, Sensation Report and Corporate Governance of Media - Evidence from Listed Companies in Our Country, Journal of Management Science, 2013, 16(10): 63-80.

[3] Shi Zhengyang, Cash Holding, Nature of Property Right and Employees' Payment in Enterprises - Evidence from Listed Companies in Our Country, Business Accounting, 2015(8): 91-93.

[4] Shen Yongjian, Liang Shangkun, Chen Donghua, etc. Employees' Payment and accounting conservatism - Based on Experimental Evidence in China's Listed Companies, Accounting Research Study, 2013(4): 73-80.

[5] Shi Liuhong, Zhang Shimiao, Feng Zhaozhen, etc. Relationship Research of Compensation Dispersion and Listed Company Performance Based on Panel Data, Modern Economic Science, 2013, 35(4): 64-73. 
